\title{
Tenacibaculum dicentrarchi sp. nov., a marine bacterium of the family Flavobacteriaceae isolated from European sea bass
}

Correspondence

Ysabel Santos

ysabel.santos@usc.es

\author{
Maximino Piñeiro-Vidal, ${ }^{1}$ Daniel Gijón, ${ }^{2}$ Carles Zarza ${ }^{2}$ and Ysabel Santos $^{1}$ \\ 1Departamento de Microbiología y Parasitología, Centro de Investigaciones Biológicas (CIBUS), \\ Universidad de Santiago de Compostela, Campus Sur 15782, Santiago de Compostela, Spain \\ ${ }^{2}$ Skretting, Ctra. de la Estación, Cojobar, Burgos 09620, Spain
}

A novel Gram-stain-negative rod-shaped gliding bacterial strain, designated $35 / 09^{\top}$, was isolated from diseased European sea bass (Dicentrarchus labrax L.) in Spain. Colonies were pale-yellowpigmented with uneven edges and did not adhere to the agar. The DNA G+C content of the isolate was $31.3 \mathrm{~mol} \%$. 16S rRNA gene sequence analysis indicated affiliation to the genus Tenacibaculum (family Flavobacteriaceae, phylum 'Bacteroidetes'). Sequence similarities between the isolate and type strains of other members of the genus were $93.1-97.3 \%$. The major fatty acids ( $>5 \%$ of the total fatty acids) were iso- $\mathrm{C}_{15: 0}(24.8 \%)$, iso- $\mathrm{C}_{15: 0} 3-\mathrm{OH}(18.0 \%)$, anteiso- $\mathrm{C}_{15: 0}(8.1 \%), \mathrm{C}_{15: 1} \omega 6 \mathrm{c}(6.9 \%)$ and iso- $\mathrm{C}_{15: 1}(6.2 \%)$. Genotypic and phenotypic data indicate that strain $35 / 09^{\top}$ should be classified as a representative of a novel species in the genus Tenacibaculum, for which the name Tenacibaculum dicentrarchi sp. nov. is proposed; the type strain is $35 / 09^{\top}\left(=\right.$ CECT $7612^{\top}=$ NCIMB $\left.14598^{\top}\right)$.
The genus Tenacibaculum proposed by Suzuki et al. (2001) belongs to the family Flavobacteriaceae (Reichenbach, 1992a, b; Bernardet et al., 1996, 2002). It currently comprises 15 species isolated from a variety of marine sources: Tenacibaculum maritimum (type species) from diseased fish (Wakabayashi et al., 1986); T. ovolyticum from fish eggs (Hansen et al., 1992); T. amylolyticum from the surface of marine macroalgae and T. mesophilum from sponges (Suzuki et al., 2001); T. skagerrakense from seawater (Frette et al., 2004); T. lutimaris, T. litoreum and T. aestuarii from tidal flat sediment (Yoon et al., 2005; Choi et al., 2006; Jung et al., 2006); T. litopenaei from shrimp mariculture pond (Sheu et al., 2007); T. discolor and T. soleae from diseased sole and T. gallaicum from seawater of a turbot holding-tank (Piñeiro-Vidal et al., 2008a, b); T. adriaticum from a bryozoan (Heindl et al., 2008); T. aiptasiae from sea anemone (Wang et al., 2008); and T. crassostreae from pacific oyster (Lee et al., 2009). In this study, we report on the detailed taxonomic characterization of strain $35 / 09^{\mathrm{T}}$, a Tenacibaculum-like isolate. During the characterization of bacteria isolated from skin lesions of diseased European sea bass (Dicentrarchus labrax L.), strain $35 / 09^{\mathrm{T}}$ was recovered on plates of Flexibacter maritimus medium (FMM; Pazos et al., 1996). Subcultivation was done on FMM and marine agar (MA; Cultimed) at $25{ }^{\circ} \mathrm{C}$ for $48 \mathrm{~h}$. The strain was preserved in Microbank tubes (Prolab Diagnostics) at $-80{ }^{\circ} \mathrm{C}$.

The GenBank/EMBL/DDBJ accession number for the $16 \mathrm{~S}$ rRNA gene sequence of strain $35 / 09^{\top}$ is FN545354.
The 16S rRNA gene sequence of strain $35 / 09^{\mathrm{T}}$ was determined by the identification service of the Deutsche Sammlung von Mikroorganismen und Zellkulturen $\mathrm{GmbH}$ (DSMZ, Braunschweig, Germany). The 1507 bp sequence of strain $35 / 09^{\mathrm{T}}$ was automatically aligned using CLUSTAL $\mathrm{W}$ (Thompson et al., 1994) with those of the type strains of the 15 Tenacibaculum species and of other representative members of the family Flavobacteriaceae obtained from EMBL. Phylogenetic trees were constructed by the neighbour-joining (Saitou \& Nei, 1987) and maximum-parsimony (Fitch, 1971) methods (Fig. 1). The evolutionary distance matrix for the neighbour-joining method was generated according to Kimura's two-parameter model (Kimura, 1980). To evaluate phylogenetic trees, a bootstrap analysis with 1000 sample replications was performed with the SEQBOOT and CONSENSE programs in the PHYLIP package (Felsenstein, 2007). The identification of phylogenetic neighbours and calculation of pairwise 16S rRNA gene sequence similarity values were achieved using the EzTaxon server (http://www.eztaxon.org/; Chun et al., 2007). Strain $35 / 09^{\mathrm{T}}$ formed a robust cluster with the 15 Tenacibaculum species in the phylogenetic tree based on 16S rRNA gene sequences (Fig. 1). The closest relatives of strain $35 / 09^{\mathrm{T}}$ were T. ovolyticum IAM $14318^{\mathrm{T}}$ ( $97.3 \%$ similarity) and T. soleae CECT $7292^{\mathrm{T}}$ (96.4\% similarity). Sequence similarities with the type strains of other Tenacibaculum species were: $T$. aiptasiae, $96.3 \%$; T. adriaticum and T. gallaicum, $95.3 \%$; T. mesophilum and T. lutimaris, 95.2\%; T. litoreum, $95.1 \%$; and T. discolor, $95.0 \%$. 


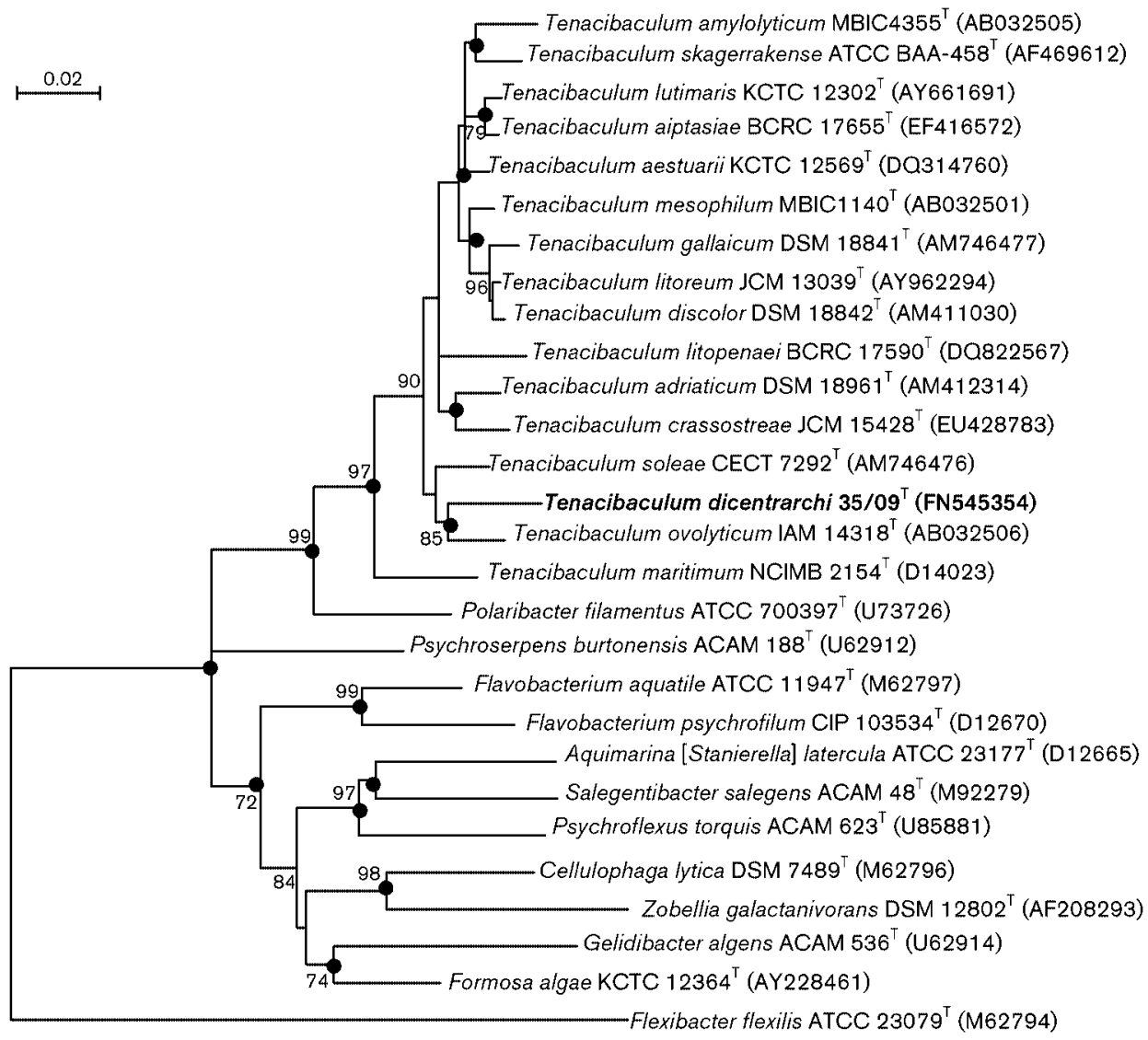

Fig. 1. Neighbour-joining phylogenetic tree showing relationships between strain $35 / 09^{\top}$, members of the genus Tenacibaculum and representatives of other related genera belonging to the family Flavobacteriaceae. The sequence of Flexibacter flexilis ATCC $23079^{\top}$ was used as an outgroup. Bootstrap values $>70 \%$ based on 1000 replications are listed as percentages at the branching points. Solid circles indicate that the corresponding nodes were also recovered in the maximumparsimony tree. Bars, 0.02 nt substitutions per site.

Morphological, physiological and biochemical tests were performed as described by Bernardet et al. (2002). The type strains of the two closest phylogenetic neighbours ( $T$. ovolyticum DSM $18103^{\mathrm{T}}$ and T. soleae CECT $7292^{\mathrm{T}}$ ) were obtained from culture collections, grown under the same conditions as the isolate and used as reference strains in all phenotypic tests. The Gram reaction was tested by using the bioMérieux Gram stain kit according to the manufacturer's instructions and the non-staining $\mathrm{KOH}$ method (Buck, 1982). Gliding motility was determined by phasecontrast microscopic examination of a fresh marine broth (MB; Cultimed) culture by the hanging drop technique as recommended by Bernardet et al. (2002). The presence of flexirubin-type pigments was determined as described by Reichenbach (1989). Catalase and oxidase activities were determined as described by Cowan \& Steel (1965). Growth under anaerobic conditions was tested on MA using the GasPak anaerobic system (BBL). Growth at $\mathrm{pH} 4-10$ (at unit intervals) was assessed in FMM broth; $\mathrm{pH}$ was adjusted using $1 \mathrm{M} \mathrm{NaOH}$ and $1 \mathrm{M} \mathrm{HCl}$. The temperature range for growth was determined on MA plates incubated at $4,8,15,18,22,25,30,37$ and $44{ }^{\circ} \mathrm{C}$ for 7 days. Salinity tolerance was tested in FMM broth containing 10, 20, 30, 50,70 and $100 \%$ strength seawater or $0.8,1.0,3.0,5.0,7.0$ and $10.0 \%(\mathrm{w} / \mathrm{v}) \mathrm{NaCl}$. Production of indole was tested in FMM broth supplemented with $1 \%(\mathrm{w} / \mathrm{v})$ tryptone as a source of tryptophan (MacFaddin, 1976). $\mathrm{H}_{2} \mathrm{~S}$ production was determined with lead acetate strips suspended above FMM broth supplemented with $5 \%(\mathrm{w} / \mathrm{v})$ peptone (MacFaddin, 1976). The Voges-Proskauer reaction was performed in seawater supplemented with $0.7 \%(\mathrm{w} / \mathrm{v})$ peptone and $0.5 \%(\mathrm{w} / \mathrm{v})$ D-glucose. Degradation of casein $(1 \%)$, gelatin $(1 \%)$, starch $(1 \%)$ and Tween $80(1 \%)$, and reduction of potassium nitrate $(0.1 \%)$ were evaluated on FMM agar (Suzuki et al., 2001). Utilization of carbon sources was tested on basal agar medium $\left[0.2 \mathrm{~g} \mathrm{NaNO}_{3}\right.$, $0.2 \mathrm{~g} \mathrm{NH}_{4} \mathrm{Cl}, 0.05 \mathrm{~g}$ yeast extract, $15 \mathrm{~g}$ agar in 11 synthetic seawater (Sigma)] containing $0.4 \%$ carbon source $[\mathrm{D}(+)$ sucrose, $\mathrm{D}(-)$-ribose, $\mathrm{D}(+)$-galactose, $\mathrm{D}$-glucose, L-proline, L-glutamate, L-tyrosine] as described by Suzuki et al. (2001). The absence of growth after 1 month of incubation was scored as a negative result. Other enzymic activities 
Table 1. Differential characteristics of strain $35 / 09^{\top}$, T. ovolyticum DSM $18103^{\top}$ and $T$. soleae CECT $7292^{\top}$

Strains: $1,35 / 09^{\mathrm{T}} ; 2$, T. ovolyticum DSM $18103^{\mathrm{T}}$; 3, T. soleae CECT $7292^{\mathrm{T}}$. All data are from this study, except the DNA G + C contents of the two reference strains taken from Suzuki et al. (2001) and PiñeiroVidal et al. (2008b). All strains are susceptible to O/129, ampicillin and novobiocin. All strains are negative for trypsin and $\alpha$-chymotrysin (API ZYM).

\begin{tabular}{|lccc|}
\hline Characteristic & $\mathbf{1}$ & $\mathbf{2}$ & $\mathbf{3}$ \\
\hline Colony morphology & & & \\
$\quad$ Shape & Uneven edge & Irregular spreading edge & Uneven edge \\
Colour & Pale yellow & Yellow & Yellow \\
Cell size $(\mu \mathrm{m})$ & $2-150 \times 0.7$ & $1.5-20 \times 0.6$ & $2-35 \times 0.5$ \\
Growth with 50\% seawater & + & + & - \\
pH range & $6-8$ & $6-10$ & $5-10$ \\
Nitrate reduction & - & - & + \\
$\alpha$-Glucosidase (API ZYM) & - & + & - \\
DNA G+C content (mol\%) & 31.3 & 30.3 & 29.8 \\
\hline
\end{tabular}

were evaluated in the API ZYM system (bioMérieux) following the manufacturer's instructions, except that sterile seawater was used as the suspension medium.

Sensitivity to antimicrobials was evaluated by the disc diffusion method following the procedures of the Clinical and Laboratory Standards Institute (CLSI, 2006), on FMM plates using commercial discs (Oxoid) containing ampicillin $(10 \mu \mathrm{g}), \mathrm{O} / 129$ (pteridine; $150 \mu \mathrm{g}$ ), and novobiocin $(30 \mu \mathrm{g})$.

The results of the morphological, physiological and biochemical tests are given in the species description and in Table 1.

For fatty acid analysis, strain $35 / 09^{\mathrm{T}}$ and the two reference strains were grown on MA for $48 \mathrm{~h}$ at $25^{\circ} \mathrm{C}$. Extraction of fatty acid methyl esters, washing of extracts and GC analysis were performed according to the standard procedures of the Microbial Identification System (MIDI; Microbial ID) (Sasser, 1990) using the MIDI Sherlock version 4.5 and TSBA40 database.

The fatty acid compositions of strain $35 / 09^{\mathrm{T}}$ and of its two closest phylogenetic neighbours are compared in Table 2. The cellular fatty acid profile of strain $35 / 09^{\mathrm{T}}$ was dominated by iso- $\mathrm{C}_{15: 0}(24.8 \%)$, iso- $\mathrm{C}_{15: 0} 3-\mathrm{OH}(18.0 \%)$, anteiso$\mathrm{C}_{15: 0}(8.1 \%), \mathrm{C}_{15: 1} \omega 6 c(6.9 \%)$ and iso- $\mathrm{C}_{15: 1}(6.2 \%)$ (Table 2). Overall, the fatty acid profiles of the three strains grown under the same conditions were very similar with only limited differences in the respective proportions of some components.

Determination of the DNA G + C content was carried out by the identification service of the DSMZ using the method described by Cashion et al. (1977). The DNA G + C content of strain $35 / 09^{\mathrm{T}}$ was $31.3 \mathrm{~mol} \%$, a value within the range reported for Tenacibaculum strains (29.8-35.2\%) (Suzuki, 2011). DNA-DNA hybridization experiments were performed using the methods described by De Ley et al. (1970), as
Table 2. Cellular fatty acid composition (\%) of strain $35 / 09^{\top}, T$. ovolyticum DSM $18103^{\top}$ and T. soleae CECT $7292^{\top}$

Strains: $1,35 / 09^{\mathrm{T}} ; 2$, T. ovolyticum DSM $18103^{\mathrm{T}} ; 3$, T. soleae CECT $7292^{\mathrm{T}}$. All data are from this study. Fatty acids amounting to $<1 \%$ of the total fatty acids in all strains are not shown. TR, Trace $(<1 \%)$; not detected.

\begin{tabular}{|c|c|c|c|}
\hline Fatty acid & 1 & 2 & 3 \\
\hline \multicolumn{4}{|l|}{ Straight chain } \\
\hline $\mathrm{C}_{14: 0}$ & 1.9 & - & TR \\
\hline $\mathrm{C}_{15: 0}$ & 3.6 & 5.6 & 4.8 \\
\hline \multicolumn{4}{|l|}{ Branched chain } \\
\hline iso- $\mathrm{C}_{13: 0}$ & 2.7 & 6.9 & $\mathrm{TR}$ \\
\hline iso- $\mathrm{C}_{14: 0}$ & 3.9 & 8.0 & 2.4 \\
\hline iso- $\mathrm{C}_{15: 0}$ & 24.8 & 11.0 & 23.1 \\
\hline anteiso- $\mathrm{C}_{15: 0}$ & 8.1 & 3.5 & TR \\
\hline iso- $\mathrm{C}_{15: 1}$ & 6.2 & 7.9 & 5.7 \\
\hline iso- $\mathrm{C}_{16: 0}$ & TR & - & 1.7 \\
\hline iso- $\mathrm{C}_{16: 1}$ & TR & $\mathrm{TR}$ & 2.4 \\
\hline \multicolumn{4}{|l|}{ Unsaturated } \\
\hline $\mathrm{C}_{15: 1} \omega 6 c$ & 6.9 & 8.2 & 12.2 \\
\hline $\mathrm{C}_{17: 1} \omega 6 c$ & TR & 1.3 & 1.7 \\
\hline \multicolumn{4}{|l|}{ Hydroxylated } \\
\hline iso- $\mathrm{C}_{15: 0} 3-\mathrm{OH}$ & 18.0 & 14.8 & 10.6 \\
\hline $\mathrm{C}_{15: 0} 2-\mathrm{OH}$ & 1.0 & - & TR \\
\hline $\mathrm{C}_{15: 0} 3-\mathrm{OH}$ & 4.0 & 5.2 & 3.2 \\
\hline iso- $\mathrm{C}_{16: 0} 3-\mathrm{OH}$ & 2.5 & 2.1 & 8.4 \\
\hline $\mathrm{C}_{16: 0} 3-\mathrm{OH}$ & 3.7 & 6.2 & 2.2 \\
\hline iso- $\mathrm{C}_{17: 0} 3-\mathrm{OH}$ & 1.1 & 1.4 & 2.9 \\
\hline Summed feature $3^{*}$ & 3.8 & 4.8 & 11.0 \\
\hline
\end{tabular}

* Summed features are groups or two or three fatty acids that cannot be separated by GLC using the MIDI system. Summed feature 3 comprises $\mathrm{C}_{16: 1} \omega 7 c$ and/or iso- $\mathrm{C}_{15: 0} 2-\mathrm{OH}$. 
modified by Huß et al. (1983). The experiment was performed at $45{ }^{\circ} \mathrm{C}$ in $2 \times$ SSC $(1 \times$ SSC is $0.15 \mathrm{M}$ sodium chloride plus $0.015 \mathrm{M}$ sodium citrate at $\mathrm{pH}$ 7.0) using a Cary 100 Bio UV/ visible spectrophotometer equipped with a Peltier-thermostatted $6 \times 6$ multicell changer and temperature controller with an in situ temperature probe (Varian). The DNA-DNA relatedness value between strain $35 / 09^{\mathrm{T}}$ and $T$. ovolyticum DSM $18103^{\mathrm{T}}$ was $12.9 \%$. On the basis of the data presented, strain $35 / 09^{\mathrm{T}}$ should be classified as a representative of a novel species of the genus Tenacibaculum, for which the name Tenacibaculum dicentrarchi sp. nov. is proposed.

\section{Description of Tenacibaculum dicentrarchi sp. nov.}

Tenacibaculum dicentrarchi [di.cen.trar'chi. N.L. n. Dicentrarchus a zoological genus name; N.L. gen. n. dicentrarchi of Dicentrarchus, isolated from the sea bass (Dicentrarchus labrax L.)].

Cells are strictly aerobic, Gram-stain-negative, straight rods, $0.3-0.5 \mu \mathrm{m}$ in diameter and $2-40 \mu \mathrm{m}$ in length (filamentous cells up to $150 \mu \mathrm{m}$ long may occur; Fig. 2a), and motile by gliding. Degenerative spherical cells are observed in ageing cultures (Fig. 2b). Colonies on FMM or MA are flat, circular with uneven edges, pale-yellowpigmented and do not adhere to agar. The pale yellow pigment is not a flexirubin-type pigment. Growth occurs in media containing 30-100\% strength seawater (optimum,
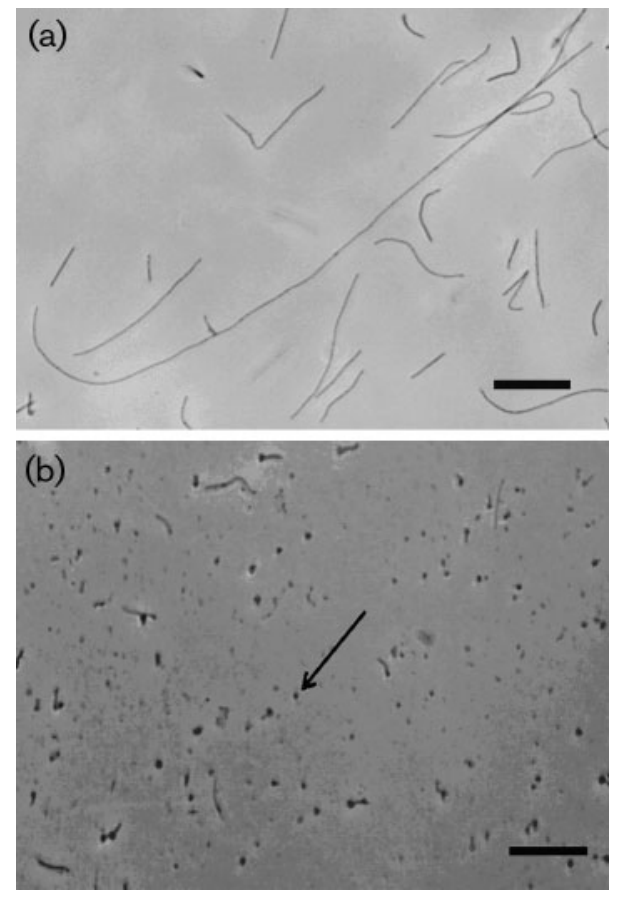

Fig. 2. Light micrographs of cells of strain $35 / 09^{\top}$ grown on $M A$ at $22{ }^{\circ} \mathrm{C}$ for $48 \mathrm{~h}$ (a) and $168 \mathrm{~h}$ (b). The arrow indicates the presence of degenerative spherical cells. Bars, $20 \mu \mathrm{m}$.
$70 \%$ ), but not in media supplemented with $\mathrm{NaCl}$ only. Growth occurs at $4-30{ }^{\circ} \mathrm{C}$ (optimum, $22-25{ }^{\circ} \mathrm{C}$ ), and at pH 6.0-9.0 (optimum, pH 7.0). Catalase and cytochrome oxidase activities are present. Gelatin and casein are hydrolysed, but Tween 80 and starch are not. The VogesProskauer test is negative. No acid is produced from carbohydrates. $\mathrm{H}_{2} \mathrm{~S}$ and indole are not produced. L-Proline, L-glutamate, $\mathrm{D}(+)$-sucrose, $\mathrm{D}(-)$-ribose, $\mathrm{D}(+)$-galactose, $\mathrm{D}(+)$-glucose and L-tyrosine are not utilized. In the API ZYM system, alkaline phosphatase, esterase (C4), esterase lipase (C8), lipase (C14), leucine arylamidase, valine arylamidase and cystine arylamidase are present, but trypsin, $\alpha$-chymotrypsin and all enzymes related to the metabolism of carbohydrates are absent. Susceptible to ampicillin, novobiocin and pteridine. The major fatty acids $\left(>5 \%\right.$ of the total fatty acids) are iso- $\mathrm{C}_{15: 0}$, iso- $\mathrm{C}_{15: 0} 3$ $\mathrm{OH}$, anteiso- $\mathrm{C}_{15: 0}, \mathrm{C}_{15: 1} \omega 6 c$ and iso- $\mathrm{C}_{15: 1}$.

The type strain is $35 / 09^{\mathrm{T}} \quad\left(=\mathrm{CECT} \quad 7612^{\mathrm{T}}=\mathrm{NCIMB}\right.$ $14598^{\mathrm{T}}$ ), isolated from diseased sea bass (Dicentrarchus labrax L.) reared in Spain. The DNA G + C content of the type strain is $31.3 \mathrm{~mol} \%$.

\section{Acknowledgements}

This investigation was partially supported by grants from the Xunta de Galicia, Spain PGIDIT 07MMA012CT, PGIDIT 08MMA017CT, PGIDIT 08MMA011200PR and INCITE 09E2R208063 ES. The authors acknowledge Dr J. P. Euzéby (Laboratoire de Bactériologie, École Nationale Vétérinaire, Toulouse, France) for his help with the species name.

\section{References}

Bernardet, J.-F., Segers, P., Vancanneyt, M., Berthe, F., Kersters, K. \& Vandamme, P. (1996). Cutting a Gordian knot: emended classification and description of the genus Flavobacterium, emended description of the family Flavobacteriaceae, and proposal of Flavobacterium hydatis nom. nov. (basonym, Cytophaga aquatilis Strohl and Tait 1978). Int J Syst Bacteriol 46, 128-148.

Bernardet, J.-F., Nakagawa, Y., Holmes, B. \& Subcommittee on the taxonomy of Flavobacterium and Cytophaga-like bacteria of the International Committee on Systematics of Prokaryotes (2002). Proposed minimal standards for describing new taxa of the family Flavobacteriaceae and emended description of the family. Int J Syst Evol Microbiol 52, 1049-1070.

Buck, J. D. (1982). Nonstaining ( $\mathrm{KOH})$ method for determination of gram reactions of marine bacteria. Appl Environ Microbiol 44, 992993.

Cashion, P., Holder-Franklin, M. A., McCully, J. \& Franklin, M. (1977). A rapid method for the base ratio determination of bacterial DNA. Anal Biochem 81, 461-466.

Choi, D. H., Kim, Y.-G., Hwang, C. Y., Yi, H., Chun, J. \& Cho, B. C. (2006). Tenacibaculum litoreum sp. nov., isolated from tidal flat sediment. Int J Syst Evol Microbiol 56, 635-640.

Chun, J., Lee, J.-H., Jung, Y., Kim, M., Kim, S., Kim, B. K. \& Lim, Y. W. (2007). EzTaxon: a web-based tool for the identification of prokaryotes based on $16 \mathrm{~S}$ ribosomal RNA gene sequences. Int J Syst Evol Microbiol 57, 2259-2261.

CLSI (2006). Methods for antimicrobial disk susceptibility testing of bacteria isolated from aquatic animals; approved guideline. CLSI 
Document M42-A, vol. 26, no. 23. Wayne, PA: Clinical and Laboratory Standards Institute.

Cowan, S. T. \& Steel, K. J. (1965). Manual for the Identification of Medical Bacteria. London: Cambridge University Press.

De Ley, J., Cattoir, H. \& Reynaerts, A. (1970). The quantitative measurement of DNA hybridization from renaturation rates. Eur $J$ Biochem 12, 133-142.

Felsenstein, F. (2007). PHYLIP (phylogeny inference package) version 3.67. Distributed by the author. Department of Genome Sciences, University of Washington, Seattle, USA.

Fitch, W. M. (1971). Toward defining the course of evolution: minimum change for a specific tree topology. Syst Zool 20, 406-416.

Frette, L., Jørgensen, N. O. G., Irming, H. \& Kroer, N. (2004). Tenacibaculum skagerrakense sp. nov., a marine bacterium isolated from the pelagic zone in Skagerrak, Denmark. Int J Syst Evol Microbiol 54, 519-524.

Hansen, G. H., Bergh, O., Michaelsen, J. \& Knappskog, D. (1992). Flexibacter ovolyticus sp. nov., a pathogen of eggs and larvae of Atlantic halibut, Hippoglossus hippoglossus L. Int J Syst Bacteriol 42, 451-458.

Heindl, H., Wiese, J. \& Imhoff, J. F. (2008). Tenacibaculum adriaticum sp. nov., from a bryozoan in the Adriatic Sea. Int J Syst Evol Microbiol 58, 542-547.

Huß, V. A. R., Festl, H. \& Scheifer, K. H. (1983). Studies on the spectophotometric determination of DNA hybridization from renaturation rates. Syst Appl Microbiol 4, 184-192.

Jung, S.-Y., Oh, T.-K. \& Yoon, J.-H. (2006). Tenacibaculum aestuarii sp. nov., isolated from a tidal flat sediment in Korea. Int J Syst Evol Microbiol 56, 1577-1581.

Kimura, M. (1980). A simple method for estimating evolutionary rates of base substitutions through comparative studies of nucleotide sequences. J Mol Evol 16, 111-120.

Lee, Y. S., Baik, K. S., Park, S. Y., Kim, E. M., Lee, D. H., Kahng, H. Y., Jeon, C. O. \& Jung, J. S. (2009). Tenacibaculum crassostreae sp. nov., isolated from the Pacific oyster, Crassostrea gigas. Int J Syst Evol Microbiol 59, 1609-1614.

MacFaddin, J. F. (1976). Biochemical Tests for Identification of Medical Bacteria. Baltimore, MD: Williams and Wilkins.

Pazos, F., Santos, Y., Macias, A. R., Núñez, S. \& Toranzo, A. E. (1996). Evaluation of media for the successful culture of Flexibacter maritimus. J Fish Dis 19, 193-197.

Piñeiro-Vidal, M., Riaza, A. \& Santos, Y. (2008a). Tenacibaculum discolor sp. nov. and Tenacibaculum gallaicum sp. nov., isolated from sole (Solea senegalensis) and turbot (Psetta maxima) culture systems. Int J Syst Evol Microbiol 58, 21-25.

Piñeiro-Vidal, M., Carballas, C. G., Gómez-Barreiro, O., Riaza, A. \& Santos, Y. (2008b). Tenacibaculum soleae sp. nov., isolated from diseased sole (Solea senegalensis Kaup). Int J Syst Evol Microbiol 58, 881-885.

Reichenbach, H. (1989). Order I. Cytophagales Leadbetter 1974. In Bergey's Manual of Systematic Bacteriology, vol. 3, pp. 2011-2013. Edited by J. T. Staley, M. P. Bryant, N. Pfennig \& J. G. Holt. Baltimore: Williams \& Wilkins.

Reichenbach, H. (1992a). The order Cytophagales. In The Prokaryotes, 2nd edn, vol. 4, pp. 3631-3675. Edited by A. Balows, H. G. Trüper, M. Dworkin, W. Harder \& K. H. Schleifer. New York: Springer.

Reichenbach, H. (1992b). Flavobacteriaceae fam. nov. In Validation of the Publication of the New Names and New Combinations Previously Effectively Published Outside the IJSB, List no. 41. Int J Syst Bacteriol 42, 327-329.

Saitou, N. \& Nei, M. (1987). The neighbor-joining method: a new method for reconstructing phylogenetic trees. Mol Biol Evol 4, 406425.

Sasser, M. (1990). Identification of bacteria by gas chromatography of cellular fatty acids, MIDI Technical Note 101. Newark, DE: MIDI Inc.

Sheu, S.-Y., Lin, K.-Y., Chou, J.-H., Chang, P.-S., Arun, A. B., Young, C.-C. \& Chen, W.-M. (2007). Tenacibaculum litopenaei sp. nov., isolated from a shrimp mariculture pond. Int J Syst Evol Microbiol 57, 1148-1153.

Suzuki, M. (2011). Genus LIII. Tenacibaculum Suzuki, Nakagawa, Harayama and Yamamoto 2001, 1650 VP. In Bergey's Manual of Systematic Bacteriology, 2nd edn, vol. 4, pp. 279-282. Edited by N. R. Krieg, W. Ludwig, W. B. Whitman, B. P. Hedlund, B. J. Paster, J. T. Staley, N. Ward, D. Brown \& A. Parte. New York: Springer.

Suzuki, M., Nakagawa, Y., Harayama, S. \& Yamamoto, S. (2001). Phylogenetic analysis and taxonomic study of marine Cytophaga-like bacteria: proposal for Tenacibaculum gen. nov. with Tenacibaculum maritimum comb. nov. and Tenacibaculum ovolyticum comb. nov., and description of Tenacibaculum mesophilum sp. nov. and Tenacibaculum amylolyticum sp. nov. Int J Syst Evol Microbiol 51, 1639-1652.

Thompson, J. D., Higgins, D. G. \& Gibson, T. J. (1994). CLUSTAL W: improving the sensitivity of progressive multiple sequence alignment through sequence weighting, position-specific gap penalties and weight matrix choice. Nucleic Acids Res 22, 4673-4680.

Wakabayashi, H., Hikida, M. \& Masumura, K. (1986). Flexibacter maritimus sp. nov., a pathogen of marine fishes. Int J Syst Bacteriol 36, 396-398.

Wang, J. T., Chou, Y. J., Chou, J. H., Chen, C. A. \& Chen, W. M. (2008). Tenacibaculum aiptasiae sp. nov., isolated from a sea anemone Aiptasia pulchella. Int J Syst Evol Microbiol 58, 761-766.

Yoon, J.-H., Kang, S.-J. \& Oh, T.-K. (2005). Tenacibaculum lutimaris sp. nov., isolated from a tidal flat in the Yellow Sea, Korea. Int J Syst Evol Microbiol 55, 793-798. 